\title{
Translation in Context as a Beneficial Teaching Approach
}

\author{
Linda Valešová, Ondřej Duda
}

\begin{abstract}
The paper deals with translation in context as a tool for enhancing students' language skills. It discusses a role of translation in English language teaching, its suppression caused by the popularity of communicative approach and its recent revival. A focus is put on context which is necessary to convey messages correctly from one language to another respecting linguistic features of both languages and stylistic characteristics of the utterance. The practical part presents a research carried out among English students (future teachers) concerning their experience with translation and its specifics at secondary schools.
\end{abstract}

Key words: translation, sentences, text, context, English language teaching.

\section{Kontextuální překlad jako přínosný přístup k výuce}

\begin{abstract}
Abstrakt
Článek se zabývá překladem v kontextu jako nástrojem pro zlepšení jazykových dovedností studentů. Pojednává o významu překladu ve výuce anglického jazyka, jeho potlačení z důvodu prosazování komunikativního přístupu a obrození překladu v posledních letech. Důraz je kladen na kontext, který je nevyhnutelný pro správný přenos sdělení z jednoho jazyka do druhého při zachování lingvistických charakteristik obou jazyků a obsahu daného sdělení. Praktická část představuje výzkum vedený mezi studenty
\end{abstract}


anglického jazyka (budoucími učiteli), který analyzuje jejich zkušenosti s překladem na středních školách a charakteristiky tohoto překladu.

Klíčová slova: překlad, věty, text, kontext, výuka anglického jazyka.

DOI: 10.5507/epd.2021.011

\section{Introduction}

The use of a foreign language involves a variety of its functions depending on the purpose of the speaker. Translation or in other words a process of conveying messages from one language to another is not only a way of using the knowledge of a foreign language practically in someone's life or for business purposes but it can also be a tool for mastering a foreign language in class. When translating (approached as a didactic tool) from the mother tongue into the target language or vice versa, students need to consider all structural and lexical discrepancies. The choice of the target language of translation, $\mathrm{L} 1$ or $\mathrm{L} 2$, will obviously determine the linguistic focus of exercises applying the methods of comparative analysis.

In many ways a language cannot be just mirrored as it is influenced by multiple external and internal conditions. When choosing appropriate language forms, students need to take into consideration much more than relying on literal translating. It is necessary to respect, among others, idiomatic and contextual character of a foreign language. Thus, this fact ought to be emphasized in foreign language lessons when teaching students how to use the language correctly and naturally in specific situations. Nevertheless, to make translation beneficial for English language teaching it is necessary for both teachers and students to be aware of its advantages and purpose.

\section{Role of translation in Foreign Language Teaching}

Translation is not only an applied skill but it can be (and should be) a methodology instrument helping students to achieve desired language competencies. In the Czech Republic, especially in 1990s the role of translation and grammar oriented teaching was marginalized due to the preference of the communicative approach which, as Hanušová (2008) notes, rejected the use of mother tongue and consequently translation in teaching process. Nevertheless, positive influence of translation has been lately rediscovered, with many authors emphasizing its role for foreign language teaching (FLT). E. g. Duff (1989) mentions indisputable arguments for the use of translation which include a positive influence of the mother tongue, nature of this activity, development of translation 
skills, language reality and usefulness for everyday life. Nunan adds that "that learners' difficulties in learning a second language can be predicted on the basis of a systematic comparison of the two languages" (Nunan, 1995, p. 144). Cook (2010) in his publication rehabilitates translation saying that "translation has pedagogic advantages both for teachers and learners, that it is both a stimulus and aid in the cognitively demanding task of acquiring a new language, and that for many users it is a very practical and much-needed skill (Cook, 2010, p.xvi). Hanáková and Metruk (2017) recommend to find a balanced approach which uses L1 to facilitate and enhance the learning absorption of $L 2$. It might be the solution to this issue along with adjusting that balance to meet the needs and levels of individual learners. (Hanáková, Metruk, 2017, p. 1).

Role of translation has a wider use than conscious comparing of mother tongue and target language. "Translation is also suitable for checking learners' knowledge. Teachers can either choose a text which comprises the taught items or they can elaborate such an exercise on their own. Here translation works as a feedback for both teachers and learners. It is obvious that the positive influence of translation in the language classroom is significant" (Stoianova, Corina, 2018, p. 254). Some authors realize a need of mother tongue for other functions in the classroom. "Mother tongue is an inseparable part of language teaching, and it actually has different functions like "rapport building purposes", "making the topic/meaning clear (by giving examples, explaining, making extra explanations, etc.)", "explaining difficult concepts or ideas", etc. (Paker \& Karaağaç, 2015, p. 111).

One of the definitions of translation says that "translation is the replacement of an original text with another text". (House, 2009, p. 3). The definition stresses that original and translated texts cannot be identical on both stylistic and lexical levels. One of the most important benefits of using translation in FLT is a conscious comparison of the mother tongue and the foreign language focusing on their cultural, structural and lexical differences. In terms of structural differences, when taking Czech and English into consideration, they are mostly determined by different typology of both languages. While Czech is a synthetic language expressing a complex lexical and grammatical notion by a single word, in an analytic language such as English, complex notions are expressed by distinctive words. These features also influence word order which is grammatical in English while observing the functional sentences perspective in Czech. Translation activities enable students to realize these differences and avoid interference or negative transfer which is, "when learners wrongly assumed a feature of the new language to be the same as in their own" (Cook, 2010, p. 88). Campbell (1998) refers to Duff $(1981$, p. 10) who sees the interference as a third language because the person, who translates, imposes the concepts of one language onto another, not moving freely from one world to another but creating a third world - a third language. Due to this third language there are many varieties of English with specific modifications depending on the countries they are used in. Although they are accepted and understood by 
the people who use them (as they share the same mother tongue), they deviate from English as a reference language. Especially in teacher training institutions it is necessary to pay attention to language accuracy as the students (future teachers) will pass on their knowledge to younger generations, they are supposed to teach such an English which is grammatically and lexically correct following standard grammar of the English language. In general, translating skills are often neglected when preparing English students at faculties of education. Kořínková (2017), who teaches translation skills at the Faculty of Education, Palacký University, points out that even though at the beginning the students are highly motivated, especially those with a high level of communicative competencies, they do not realize how difficult it can be to translate the source English text into their mother tongue. It is not surprising that their first texts are translated quite literally and were stylistically inappropriate. Řeřicha (2017) adds that one of the ways to practise translation while emphasizing structural differences between source language and target language is back translation which has been used mostly in specific professional texts but it can also be a relevant didactic tool. If the content of the text is more difficult and contains a larger amount of the unknown lexical language items, free translation is recommended. When the second type is applied learners should be able to translate it involving the knowledge of grammar and vocabulary they have learnt so far. (Stoianova, Corina, 2018 p. 254).

\section{Context and meaning}

The previous chapter shows that there are certain layers of meaning which a translator/ learner needs to become aware of when translating or interpreting a text. Yet, these layers are determined either linguistically or by the participants of the communicative process and their subjective understanding. Nevertheless, each communication, as well as translation, is conveyed within a linguistic context made up of words or sentences but also within an extralinguistic context. The overall context of the classroom translation must be broad enough to support a complete understanding of L1. The concept of the context of situation was more developed by the social anthropologist Malinowski who did not include only spoken words, but also facial expression, gestures, bodily activities, all people present during an exchange of utterances and the part of the environment in which these people are engaged (Kramsch, 1993, p. 37).

No item of language can be isolated from the environment in which it is located. The use of a foreign language, its interpreting, translating or understanding might lead to wrong conclusions if the meaningful context is not presented. "Our choice of words is constrained by the context in which we use the language" (Kramsch, 1993, p. 34). If not respecting the context, the use of language can lead to an inappropriate utterance, unexpected consequences or even to misunderstanding. Moreover, language meaning 
might shift depending on the context in which it is used. When we take an example of the phrase "press here", it has several meanings that can be decoded only with knowledge of the general context it is used in. Without the context it is not possible to say if this phrase is an instruction to operate a machine, a note for the newspaper employees or a part of an architect's plan.

\subsection{Context in the class}

Teaching a foreign language in a class creates a context with specific features. The target language is mostly used in its neutral form often following the topics of the study. Unfortunately, in many cases the class is removed from real-world situations. Thus, a qualified and experienced teacher should bring "this outside world" to the class by designing such tasks and situations which imitate real world making students use appropriate utterances to achieve their communicative goals. Richards (1985) refers to the research by D'Anglejan who "attributes failure in classroom language learning to the fact that it is often not embedded in the context of social interaction and focuses on language as an entity rather than on language as communication" (Richards, 1985, p. 81). For these reasons it is very important to teach students a foreign language within its general context, i.e. all circumstances determining its form and meaning.

\section{Research}

The research was implemented in the program survio.com gathering answers in online questionnaires and evaluating them at the same time. It is an effective tool for our quantitative research attempting to find out whether translation in context has been a part of English language teaching at secondary schools and if so, what are the specifics. Only when these questions have been answered can more specific issues of classroom translation be dealt with. A method applied for gaining results has been an anonymous online questionnaire completed by the English students in their first year at the Faculty of Education, Palacký University. The reason for selecting this sample of respondents (non-probability sampling) was to involve those students who have a high level of English and are interested in this subject. Moreover, as future English teachers who study English not only practically but theoretically as well, they tend to be more competent to objectively answer the given questions. 


\subsection{Respondents and their previous studies}

The first two questions deal with students' previous education, i.e. the type of secondary school and the year they left it. These two pieces of information would have influenced students'learning experience as general grammar schools are supposed to have a higher level of English teaching than other secondary schools. We expect that most of the students left their secondary schools recently as all respondents are full time university students.

There were 80 respondents involved in the questionnaire, 59 of them graduated from grammar school which confirms our assumption that most of the students studying at the university previously attended this type of school. Regarding the academic program of the Faculty of Education it is not surprising that 9 of the respondents graduated from an education oriented secondary school. The rest of the respondents graduated from other secondary schools. In terms of the graduation year no-one had finished secondary school before 2018 which means that all respondents have been influenced by current teaching trends.

\subsection{Analysis of questions}

The analysis of the questionnaire includes questions which are further commented on the basis of graphically described responses.

\section{Did you translate in English classes at the secondary school?}

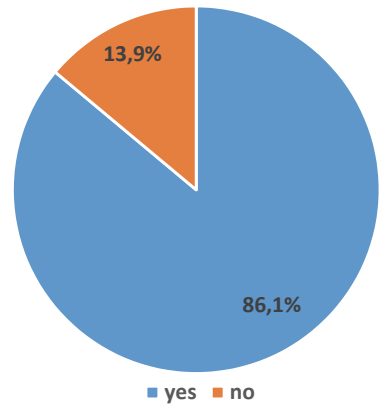

It is clear that translation is an important part of English language teaching at secondary schools as most of the teachers do not rely on the target language only avoiding the mother tongue, as more than $86 \%$ of respondents practised translation in their English classes. We can conclude that despite the prevalence of communicative approach which was emphasized in 1990s, in today's English classes we can see a revival of translation 
which was as a method popular before communicative approach. Next two questions aim to find out more specific information dealing with translating; that is how often sentences and texts were translated.

\section{How often did you translate sentences?}

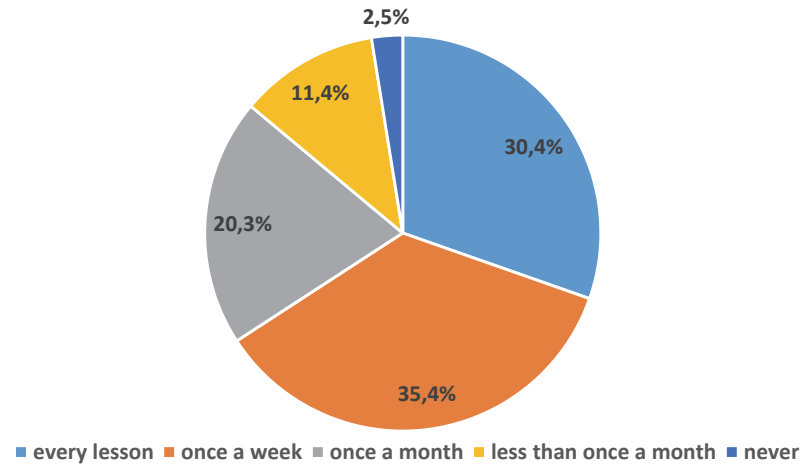

\section{How often did you translate texts?}

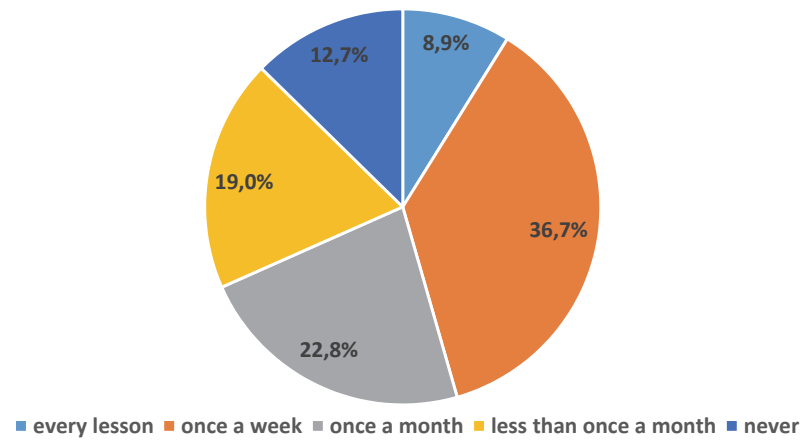

While translating sentences is beneficial especially for emphasizing structural differences between the source and the target languages and providing linguistic context, translating text can involve extralinguistic context which reveals more factors that influence communication. When comparing the two graphs, it is obvious that translating sentences is more common and regular in English classes than translating texts. Almost $30 \%$ students responded that they translated sentences every lesson, two times more in comparison with texts translation where the number is lower than $10 \%$. In the case 
of the answer never, only 2,6\% never translated sentences while $12,8 \%$ never translated texts. The reason for this disproportion might be explained by the fact that for teachers it is easier to choose or make up linguistically and lexically relevant sentences but to prepare texts which fulfil all requirements is more demanding and takes more time for both preparation and for its use.

There is an obvious correlation between the frequency of translating sentences and texts. Most of those respondents who translated sentences less frequently (less than once a month), had the same or lower frequency of translated texts and more than a half of them had never translated texts. It proves that translating texts is practised only in the classes where sentences are translated, in other words, translating sentences builds a base for translating texts as a higher level of translation and a more complex activity.

\section{Did you enjoy translating?}

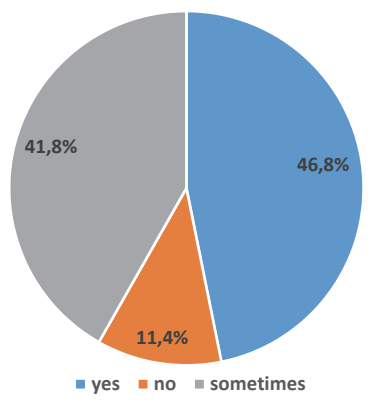

5. Do you think that translation has helped you to improve your English language skills?

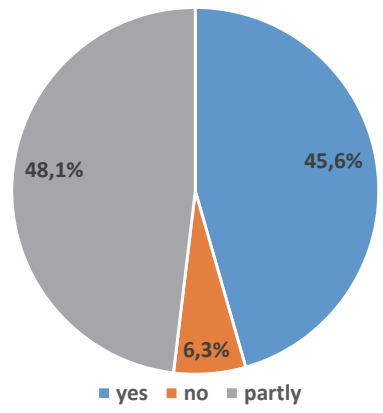


One of the arguments against using translation in FLT might be that this activity is boring for students and not as beneficial as monolingual approach. The presented graphs show that it is disputable. In the first case, more than $88 \%$ respondents enjoy or at least sometimes enjoy translating. It is probable that popularity or unpopularity of translation does not depend on the activity itself but on the source of the translation and the methodology teachers use practicing this activity in the classroom. Updated topics involving students' interests and varying tasks for translation which might involve working in groups or a competition can liven up the lesson to a large extent. In terms of the benefits of translation from the respondents' point of view, only $6 \%$ think that this activity has not helped them to improve English language skills at all.

In the graphs number 4 and number 5 we can also find a correlation between a positive attitude to translating and accepting it as a tool which helps students improve English language competencies. The students who think that translating is not beneficial for their knowledge of English in most cases do not enjoy translating. This is quite expected as commonly students enjoy those class activities which they find useful.

\section{Did your course book include translation activities?}

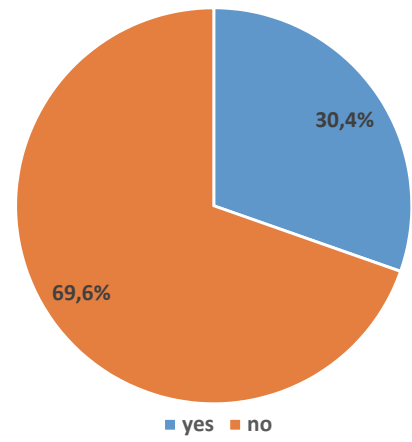

The "boom" of communicative approach in 1990s influenced not only the methodology of ELT but also the choice of course books used at specific levels of education. In spite of the fact that all present teachers have infinite sources for finding and composing teaching material which would suit their needs, it is common that the basic material is a course book which not only follows curriculum but includes most of the task and exercises students work on in their English lessons. Monolingual course books having been in use since 1990s all over the world are useful and practical but lack the aspect of interlingual relation between the mother tongue and English. As the presented graph number 6 shows, almost $70 \%$ respondents agree that their course book did not include any translation activities. We do not claim that the concept of current course books is 
wrong but it should focus more on comparison of target language and native language of users especially from the structural and contextual point of view.

\section{Did you use pictures to explain context?}

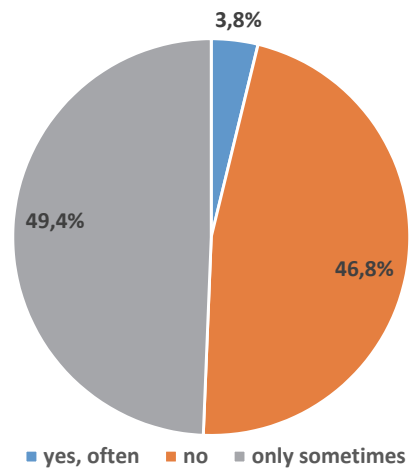

Although pictures are important part of each modern course book and their distribution in current teaching materials is much broader than in the past, we can see that they are not commonly used for providing context in translation activities. Almost half of the students responded that they did not use pictures when translating and approximately the same number used them only sometimes. Pictures can illustrate a situation with all its details which may be important when choosing the context-relevant language for translation, however, for limitations of pictorial adjuncts $\mathrm{cf}$. Temptations of the Didactic Illustration (Práger \& Řeřicha, 2020).

\section{Conclusion}

Although the methodology of English language teaching is developing all the time, translation as a teaching tool has always been an important part of it. Conveying information from one language to another helps students realize how both languages work and what differences they need to focus on either understanding a regularly repeated pattern of contrast or individual differences which are needed to be memorized. As each language is a system formed by linguistic and extralinguistic features, it is necessary to provide students with sufficient context which can clarify the utterance and increase the benefits of translation for students' language competences. The research has proved that the students of English (future English teachers) consider translation to be a useful tool which can be enjoyable and at the same time it can enhance their 
language skills. On the other hand, considering their answers, translating individual sentences prevails over translating texts which are rich in context and therefore can provide students with additional information of extralinguistic character. The contribution of pictorial adjuncts that may illustrate contexts and provide more information are not sufficiently considered. It may be concluded that translating activities would be of significant benefit for teaching the English language in context especially when focusing on higher language proficiency when students need more information to be able to choose the most suitable grammatical and lexical option and eventually master the stylistic characteristics of the target language.

\section{References}

Campbell, S. (1998). Translation into the Second Language. Essex: Addison Wesley Longman Limited. Cook, G. (2010). Translation in Language Teaching. Oxford: Oxford University Press.

Duff, A. (1996) Translation. Oxford: Oxford University Press.

Hanušová, S. (2008). Metody cizojazyčné výuky. [online]. Brno: Masarykova Univerzita, 2008. Dostupné z file:///C:/Users/uzivatel/AppData/Local/Temp/Metody\%20cizojazyčné\%20výuky \%20-\%20Světlana\%20Hanušová-1.pdf

Hanáková, M., \& Metruk, R. (2017). The use of I1 in the process of teaching English. Modern Journal of Language Teaching Methods, 7(8), 380-389.

House, J. (2009). Translation. Oxford: Oxford University Press. ISBN 978-0-19-438922-8

Kořínková, J. (2017). Překladatelská cvičení pro pokročilé studenty angličtiny na Pdf UP. In Hrdinová, E. M. et al., Překlad jako didaktický nástroj ve výuce cizích jazyků. (s. 81-92). Olomouc: UP.

Chmelařová, L., \& Hornová, L. (2008). Možnosti precvičovania anglickej gramatiky a význam prekladu vo výuke anglického jazyka. In Kasáčová, L. et al. Prostriedky edukácie v škole 21. storočia. Banská Bystrica: Univerzita Mateja Bela, Pedagogická fakulta, Centrum vzdelávania doktorandov pri PF UMB.

Chmelařová, L. (2009). Překlad ve světle moderního komunikativního přístupu. In Obenausová, S. New Trends in Educating Future Teachers of English V. Olomouc: UP.

Chmelařová, L. (2013). Gramatika a překlad ve výuce cizího jazyka. In Procházková, Z. et al. Metodický poradník učitele cizího jazyka. Ústí nad Labem: UJEP.

Kramsch, C. (1993). Context and Culture in Language Teaching. Oxford: Oxford University Press.

Nunan, D. (1995). Language Teaching Methodology. England: Phoenix ELT.

Paker, T., \& Karaağaç, Ö. (2015). The use and functions of mother tongue in EFL classes. ProcediaSocial and Behavioral Sciences 199(2015), 111-119.

Práger, L., \& Řeřicha, V. (2020). Temptations of the Didactic Illustration. Hradec Králové Journal of Anglophone Studies, 7(1), 12-21.

Valešová, L., \& Duda, O. (2020). English for Educators and its place in the university curriculum. Hradec Králové Journal of Anglophone Studies, 7(1), 22-31.

Řeřicha, V. (2017). Didaktické možnosti zpětného překladu textů v informativním stylu. In Hrdinová, E. et al. Překlad jako didaktický nástroj ve výuce cizích jazyků. Olomouc: UP.

Richards, C. J. (1985). The Context of Language Teaching. Cambridge: Cambridge University Press.

Stoianova, I., \& Ivaniuc, C. (2018). Using translation in EFL classroom: challenges and perspectives. In Preocupări contemporane ale științelor socio-umane. Chişinău: "Print-Caro” SRL. 


\section{Contacts:}

Mgr. Linda Valešová, Ph.D.

Mgr. Ondřej Duda

Institute of Foreign Languages, Faculty of Education, Palacký University

Žižkovo nám. 5, 77140 Olomouc, Czech Republic

e-mails: linda.valesova@upol.cz; ondrej.duda@upol.cz

Linda Valešová teaches and guarantees English for Educators courses at the Faculty of Education, Palacký University in Olomouc, the students not majoring in Teaching English as a foreign language. The course is designed to teach English for specific purposes in the field of pedagogy and psychology. Her research focuses on future lower secondary teachers' language competencies and their language needs analysis. Part of her research is devoted to translation as a teaching tool in contemporary elementary school.

Ondřej Duda is Assistant Professor of the English language at the Institute of foreign languages at the Faculty of Education, Palacký University in Olomouc. He teaches sociolinguistics, methodology of teaching and ICT courses. His academic interests include the development of future English teachers' competences, use of ICT in teaching, and out of school language learning. He has participated in ERASMUS+ GULL, LEEN, VOICES, IINTOS and WAVE-IT projects. 